\title{
PROFESSIONAL DISCOURSE OF CONTRASTIVE GRAMMAR TEXTBOOKS: THE PROBLEM OF INTERPRETATION OF KEY TERMS
}

\author{
Kovtun O. V.
}

\author{
The whole mechanism of language is based solely \\ on similarities and differences \\ (Ferdinand de Saussure)
}

\section{INTRODUCTION}

Comparative studies in linguistics have a long history. Comparison is a general scientific method of research, which is used along with logical analysis, generalization, description and other methods. It is traditionally believed that the heyday of comparative linguistics was the XIX century, but the method of comparative or contrastive analysis remains the main in linguistic research in the XX and XXI centuries, and contrastive grammar has become the main principle of foreign language teaching, so textbooks on this subject are paramount.

Comparison or contrast is a property of abstract human thinking, a way of knowing reality, differentiation of similar objects and phenomena, so the category of comparison in logic and philosophy belongs to the key epistemological categories. It is the diversity of the world that determines the constant comparison of human consciousness of different phenomena.

Many things, especially in the mental sphere, in the sphere of traditions and habits of the people, public institutions can be understood only by comparison, i.e. it is necessary to find in this or that object something different from the object familiar to us to realize that the usual object has some other features, qualities, properties or, conversely, to understand what it lacks, why there are no certain features, qualities, properties, characteristics ${ }^{1}$.

The term comparative (contrastive or confrontational) linguistics is interpreted in science in many ways, including as a linguistic direction that studies two or more languages to compare their structures and identify

1 Стернин И.А., Стернина М.А. Актуальные проблемы сопоставительных исследований в современной лингвистике. Социальные и гуманитарные знания. 2015. № 1. С. 59-65. 
differences (contrast / non-contrast) against the background of similarity ${ }^{2}$. It is an established science with its own object, goals and methods of analysis.

According to Anatoliy Zagnitko, comparative linguistics (comparative studies) is a direction (sphere) of linguistics that studies two or more languages, regardless of their affinity, to identify their similarities and differences at all levels of language structure (phonological, morphological, syntactic, lexico-semantic $)^{3}$.

The general task of comparative-historical linguistics is, as it is well known, to establish the peculiarities of the kinship of languages (genealogical proximity), to determine the laws of genealogical classification, to reconstruct their proto-language and to reveal the laws of historical development of individual languages and groups of languages. The main method that appears to be the most acceptable in comparativehistorical linguistics is the comparative-historical method.

The term comparative studies also mostly refers to comparativehistorical linguistics, but is sometimes used in a broader sense - to denote the whole set of disciplines based on the comparison of languages (in addition to comparative-historical linguistics, also typological and comparative linguistics) ${ }^{4}$.

The theoretical and practical purpose of the contrastive study of two languages is grammar, the content of which is a description of the sum of the differences between the grammar of the native language and the grammar of the language being studied. Thus, contrastive grammar is considered as differential grammar. Contrastive analysis is indispensable in language teaching, as it makes it possible to predict areas of interference in the activity of the phenomenon of interference, promotes conscious mastery of language.

\section{The problem of interpretation of key terms of contrastive grammar}

In modern linguistics there are many terms for the nomination of a section of linguistics that studies two or more languages on the basis of their comparison and contrast. However, depending on the purpose and object, there are branches of linguistics based on comparison. It is first of all (a) comparative-historical linguistics, which studies the genetic commonality of languages in their development; (b) areal linguistics, which considers the secondary affinity of languages, linguistic unions, commonality of linguistic phenomena, regardless of the degree of their

\footnotetext{
2 Загнітко А. Сучасний лінгвістичний словник. Вінниця : ТВОРИ, 2020. 920 с.

3 Загнітко А. Словник сучасної лінгвістики : поняття і терміни. Донецьк : ДонНУ, 2012. Т. 2. 350 с.

4 Загнітко А. Словник сучасної лінгвістики : поняття і терміни. Донецьк : ДонНУ, 2012. Т. 2. 350 c.
} 
genetic commonality; (c) comparative and contrastive linguistics, which study the similarities and differences between languages, regardless of the degree of their genetic similarity, etc. ${ }^{5}$

This diversity is due to the goals, principles and criteria that underlie the selection of a particular field of linguistics, engaged in the comparison and contrast of languages. However, there are different views on the feasibility of terminological distinction between comparative and contrastive linguistics.

Contrastive linguistics as a science was formed in the middle of the XX century in English-speaking countries. The beginning of contrastive research is considered to be the publication of Robert Lado's monograph "Linguistic across cultures" 6 and Charles Bally's ${ }^{7}$ research, who justified the need to teach German in a French-speaking audience.

All grammars of the studied second language and many first grammars of the native language were written with the involvement of methods of comparison, conscious or unconscious, with another language - native one in the first case or more prestigious language of culture - in the second case.

Researchers believe that the European grammars of the Renaissance the first grammars of modern languages - were actually created in comparison with the grammars of Greek or Latin. Obviously, the modern linguist who describes a foreign language or dialect always relies on the usual scheme of "vision" of mostly native language or sometimes some other, with which he involuntarily compares the facts of new language being researched, passing them through the usual network of concepts, fixed in his consciousness. Let's recall that language consciousness is a form of consciousness that embraces knowledge, feelings, evaluations and guidelines for language and language activities, or language consciousness - it is a "not indifferent attitude to language"

Comparative linguistics is primarily based on the need to describe languages in order to teach them. Therefore, modern contrastive linguistics

${ }^{5}$ Євтушенко Н.І. Контрастивний та зіставний аспекти досліджень у сучасній лінгвістичній. Наукові праці Чорноморського державного університету імені Петра Могили комплексу «Києво-Могилянська академія». Серія : Філологія. Мовознавство. 2014. Т. 221. Вип. 209. С. 24-28.

${ }^{6}$ Lado R. Linguistics Across Cultures: Applied Linguistics for Language Teachers. University of Michigan Press, 1957. $141 \mathrm{p}$.

${ }^{7}$ Bally Ch. Traité de Stylistique Française. (3rd. ed., 2 vol.) Paris : C. Klincksiek, 1951. 264 p.

8 Селігей П.О. Мовна свідомість: структура, типологія, виховання / НАН України. Інститут мовознавства ім. О.О. Потебні. Київ. Вид. дім «КиєвоМогилянська академія». 2012. С.13 (118 с.). 
is a kind of sublimation, a theoretical generalization of the ancient human practice of language description.

Eleonora Suleimenova emphasizes that contrastive linguistics establishes the similarities and the differences of languages that are compared and, therefore, it focuses on finding the most effective ways to learn one (or more) languages. In her opinion, the object of contrastive analysis can be absolutely all linguistic phenomena that meet the tasks of an applied nature?

Veronica Yartseva considers the terms comparative linguistics and contrastive linguistics as synonymous. The researcher is convinced that the second term in the given pair is given a certain advantage because of its greater traditionalism, prevalence and emphasis on the selection of dissimilar (contrasting) features ${ }^{10}$. Reflecting on contrastive lexicology, Professor V. Yartseva writes that "bilingual dictionaries always contain in their infancy a contrastive comparison of lexical units" ${ }^{\prime 1}$, but the development of field theory and methods of component analysis creates a new basis for contrastive lexicology.

Valery Mokienko considers such a distinction significant, important, because the first term (comparative linguistics) mainly refers to the focus on the differential features of the languages being compared, and the second focuses on the process of comparison, for which both interlingual differences and similarities are important ${ }^{12}$.

Aloizas Gudavičius distinguishes between the concepts of contrastive and comparative linguistics. He is convinced that contrastive analysis is limited to two languages and is intended mainly for the implementation of applied tasks, among which primary tasks are linguodidactic ones. In his opinion, a kind of contrastive research is the study of one language "in the mirror" of another ${ }^{13}$. Thus, a certain language is studied and, in particular, those features, which may distinguish it from the original language, usually native.

Considering the relationship between such sections of linguistics as comparative linguistics and contrastive linguistics in view of the purpose, objectives, methods and general principles of the study, Fatima Isenova insists that "unlike comparative linguistics, the subject of contrastive linguistics is determined by the linguodidactic orientation of language

9 Сулейменова Э.Д. Казахский и русский языки: основы контрастивной лингвистики. Алматы : Демеу, 1996. 208 с.

${ }_{10}$ Ярцева В.Н. Контрастивная грамматика. Москва : Наука, 1981. 111 с.

${ }^{11}$ Ярцева В.Н. Контрастивная грамматика. Москва, 1981. $111 \mathrm{c.}$

12 Мокиенко В.М. Сопоставление в теории и практике преподавания русского языка как иностранного. Русский язык за рубежом. 1987. №5. С. 54-60.

${ }^{13}$ Гудавичюс А. Сопоставительная семасиология литовского и русского языков. Вильнюс : Мокслас, 1985. 176 с. 
comparison, which will help to identify and describe such differences that, being found in languages, will help to learn a second (foreign) language better, will be able to explain cases of inconsistency in grammatical and conceptual language systems" ${ }^{\prime 14}$. V. Yartseva notes that in contrastive research the comparative method is used, the essence of which is to "study and describe a language through a systematic comparison with another language in order to clarify its specificity"15. Vadim Kasevich in his work «Фонология в типологическом и сопоставительном изучении языков» ("Phonology in the typological and comparative study of languages") writes that "comparison, contrast is the basis of typology, and comparativehistorical linguistics, and areal linguistics. What features of comparative linguistics are different? There seem to be two solutions. One is to consider "comparative linguistics" as a general nomination for the mentioned (...) branches of linguistics. Another is, on the contrary, to narrow this concept, to identify it with contrastive linguistics. In contrastive linguistics, the linguistic, mainly typological method of research, and the psycholinguistic and sociolinguistic methods must be combined"16.

According to Volodymyr Hak, typology, comparative, confrontational and contrastive linguistics are different terms. Contrastive linguistics appears as an already formed science with its object, goals and methods of analysis. "The development and values of the contrastive-linguistic direction in linguistics is evidenced by the publication of more and more works, general theoretical descriptions of contrastive linguistics, comparative description of language pairs covering different levels of language - from phonology to stylistics and text theory, expanding the scope of comparative analysis: at first, contrastive analysis dealt mainly with the facts of the language system, now it is increasingly turning to the text, language acts, implementation, following the general direction of development of modern linguistics ${ }^{17}$.

In the dictionary of linguistic terms by Veronica Yartseva nominations comparative linguistics, typology and confrontational linguistics are given as synonyms of the term contrastive linguistics ${ }^{18}$. We observe the same in

${ }^{14}$ Исенова Ф.К. Сопоставительное языкознание и контрастивная лингвистика в современной языковой парадигме. Вестник КарГУ. Сер. филологическая. Караганда : КарГУ, 2007. № 1. С. 71-77.

15 Лингвистический энциклопедический словарь / гл. ред. В.Н. Ярцева. Москва : Советская энциклопедия, 1990. 688 с.

16 Касевич В.Б. Фонология в типологическом и сопоставительном изучении языков: Методы сопоставительного изучения языков. Москва : Наука, 1981. 94 с.

${ }^{17}$ Гак В.Г. О контрастивной лингвистике. Новое в зарубежной лингвистике. Москва : Прогресс, 1989. 438 с.

18 Лингвистический энциклопедический словарь / Гл. ред. В.Н. Ярцева. Москва : Советская энциклопеция, 1990. 688 с. 
Anatoliy Zagnitko's dictionary, where it is stated that the term comparative linguistics is synonymous with contrastive linguistics and confrontational linguistics $^{19}$.

Iryna Karamisheva considers contrastive grammar as a component of contrastive linguistics (comparative linguistics), and its research object is grammatical structures of two contrasted languages, features of expression of main grammatical categories and syntactic structures in contrasted languages. The researcher clearly distinguishes between contrastive linguistics and comparative-historical, typological and areal, although all these independent scientific directions use comparative and contrastive methods of linguistics ${ }^{20}$. The researcher believes that contrastive linguistics still does not have a properly prescribed status in the system of linguistic disciplines. The question of whether this science belongs to general or special linguistics, synchronous or diachronic, remains debatable. To determine the status of contrastive linguistics, it is considered appropriate to clarify its links with other mentioned linguistic directions ${ }^{21}$.

Contrastive grammar is a direction (component) of contrastive linguistics. Contrastive grammar is aimed at establishing (a) common and (b) heterogeneous, as well as (c) dominant and (d) recessive features of the grammatical structure of the languages being compared, and (e) determining their structural types on this basis.

The number of languages that can be typologically contrasted at the same time is not limited. Contrastive research can focus on a variety of linguistic phenomena, ranging from individual features of phonetic / phonological, morphological, lexical or syntactic phenomena of languages ${ }^{22}$. This view is reflected in "Encyclopedia of Hebrew Language and Linguistics", which emphasizes that contrastive grammar studies the synchronous analysis of the similarities and differences between two or more languages ${ }^{23}$.

Some scholars interpret contrastive linguistics somewhat more narrowly and contrast it with confrontational linguistics. This understanding can be traced in the works of Gustav Helbig ${ }^{24}$. This linguist is convinced that

19 Загнітко А. Сучасний лінгвістичний словник. Вінниця : ТВОРИ, 2020. 920 с.

${ }^{20}$ Karamysheva I.D. Contrastive grammar of English and Ukrainian Languages: Textbook; Second edition, revised. Vinnytsia : Nova Knyha Publishers, 2012. 320 p.

${ }^{21}$ Karamysheva I.D. Contrastive grammar of English and Ukrainian Languages:

Textbook ; Second edition, revised. Vinnytsia : Nova Knyha Publishers, 2012. 320 p.

${ }^{22}$ Гладуш Н.Ф., Павлюк Н.В. Contrastive Grammar: Theory and Practice. Київ : Київський ун-т. ім. Б. Грінченка ; Нац. ун-т Києво-Могилянська акад., 2019. 296 с.

${ }^{23}$ Khan G. Encyclopedia of Hebrew Language and Linguistics. Brill, 2013.

24 Хельбиг Г. Языкознание - сопоставление - преподавание иностранных языков. Новое в зарубежной лингвистике. Москва : Прогресс, 1989. Вып. XXV. Контрастивная лингвистика. С. 307-326. 
confrontational (this term corresponds to the Ukrainian "comparative") linguistics is more designed to develop questions of theory: it studies both the similarities and the differences that exist between languages, and contrastive linguistics has a more practical focus and explores mostly differences between languages.

Some scholars focus their research on the actualization of contrastive research exclusively for the study of a foreign language. For example, this view can be traced to the authors of one of the popular textbooks on contrastive grammar ${ }^{25}$, who note that contrastive linguistics compares two languages in order to facilitate language learning by identifying important differences between native and target languages. Contrastive linguistics studies exactly how (positively or negatively) the identified differences affect the study of the target language. The main purpose of contrastive linguistics is the study of contrastive grammar, which combines descriptive grammars of two languages in one unique form ${ }^{26}$.

Analysis of the works of famous scholars on the problem of contrastive and comparative aspects of language research allows us to conclude that the basis of contrastive linguistics is the principle of taking into account the opposition synchrony - diachrony.

The comparative (comparative-historical) direction of linguistics, as it was noted, has a long tradition; its methodology, object, subject, metalanguage were duly substantiated by its founders in the XIX century (Franz Bopp $^{27}$, Rasmus Rusk ${ }^{28}$, Jacob Grimm ${ }^{29}$ and Alexander Vostokov ${ }^{30}$ ). This direction studies languages in diachrony (mostly Indo-European) taking into account the genetic origin of languages; at the same time related languages are studied, first of all closely related ones.

Comparative (comparative-typological) direction of linguistics is a little younger: it counts about four decades. Its methodology, object, subject, metalanguage and methods of analysis are substantiated in Soviet linguistics

${ }^{25}$ Meehan P., Gomez Calvillo N., Díaz M. J., Rolfi L. Contrastive grammar: a theory and practice handbook. Córdoba: Asociación Cooperadora Facultad de Lenguas - UNC, 2017. 245 p.

${ }^{26}$ Meehan P., Gomez Calvillo N., Díaz M. J., Rolfi L. Contrastive grammar: a theory and practice handbook. Córdoba: Asociación Cooperadora Facultad de Lenguas - UNC, 2017. 245 p.

${ }^{27}$ Bopp F.A Comparative Grammar of the Sanscrit, Zend, Greek, Latin, Lithuanian, Gothic, German and Sclavonic Languages. London: Williams, 1885. 456 p.

${ }^{28}$ Rask R.Ch. A Grammar of the Danish language for the use of Englishmen, 1830.

${ }^{29}$ Grimm J. Geschichte Der Deutschen Sprache. Erster Band. Leipzig, 1853. 1250 gr.

30 Востоков А.Х. Грамматика церковнославянского языка, изложенная по древнейшим оного письменным памятникам. Санкт-Петербург : в тип. Имп. акад. наук, 1863. $134 \mathrm{c}$. 
(Vladimir Arakin $^{31}$, Vladimir $\mathrm{Gak}^{32}$, Mikhail Kochergan ${ }^{33}$, Veronika Yartseva ${ }^{34}$ ). This area studies languages mainly in synchrony and focuses on unrelated languages or languages that are remotely related.

Thus, comparative-historical linguistics explores (a) proto-forms, (b) speech schemes, (c) the processes of development of related languages, i.e. languages are compared in terms of diachrony. Comparative linguistics studies several languages in a synchronous-comparative aspect, revealing cases of (a) complete, (b) partial coincidence or (c) facts of differences of different language levels ${ }^{35}$.

Based on the analysis, we see that the object of contrastive studies is at least a pair of languages. But neither genetic or areal connections, nor the typological proximity or remoteness of these languages are significant in the comparison process. The subject of contrast may be differences or correspondences of the contrasted languages. This type of differences and correspondences exist at all levels of language. Within the framework of contrastive linguistics it is possible to compare phonetic and phonological, lexical and phraseological, morphological, syntactic systems of two languages. The results of such research are useful in the study of foreign languages. But the basis of contrastive research is the dual relationship between the plan of expression and content (form and content) of the contrasted languages.

The purpose of contrastive linguistics is to determine the distinctive and common features of the compared languages. In this it is close to typological and comparative linguistics. Contrastive linguistics pays special attention to the dissimilar features of languages. Contrastive research pursues not only theoretical but also practical goals. Thus, the theoretical and practical purpose of the contrastive study of two languages, as noted by researchers, the construction of grammar, the content of which is a description of the sum of differences between the grammar of the native language and the grammar of the language being studied. Thus, contrastive grammar is a kind of differential grammar. But this does not mean that grammatical sectors that coincide in two languages should not be studied. Such an approach would

31 Аракин В.Д. Сравнительная типология английского и русского языков : Учебное пособие. 3-е издание. Москва : Физматлит, 2005. 232 с.

${ }^{32}$ Гак В.Г. О контрастивной лингвистике. Новое в зарубежной лингвистике. Москва : Прогресс, 1989. 438 с.

${ }_{33}$ Кочерган М.П. Основи зіставного мовознавства: Підручник. Київ : Академія, $2006.424 \mathrm{c}$.

${ }^{34}$ Ярцева В.Н. Контрастивная грамматика. Москва, 1981. 111 с.

35 Євтушенко Н.І. Контрастивний та зіставний аспекти досліджень у сучасній лінгвістичній. Наукові праџі Чорноморського державного університету імені Петра Могили комплексу «Києво-Могилянська академія». Серія : Філологія. Мовознавство. 2014. Т. 221. Вип. 209. С. 24-28. 
inevitably lead to a misinterpretation of the facts of the language being studied. The results of the comparison of the two languages are necessary to predict the difficulties and errors that arise in the process of learning nonnative languages. Of course, in the practical use of data from contrastive linguistics in the study of languages, it is necessary to focus more on differences than on similarities, but when comparing languages, both similarities and differences are inevitably noted. There is no fundamental difference here. In comparative studies, it is important to note the isomorphism of allomorphic facts. Therefore, there is no reason to oppose confrontational and contrastive, both approaches use the same research methods, but the most important is something that is taken into account primarily when using its results.

The term contrastive linguistics in modern linguistics is necessary because this area has (1) a special purpose, which is realized during the study of languages - it is a systematic separation of differences, (2) own method of language learning - from native to foreign, and 3) a kind of practical application in the teaching of foreign languages. All this testifies in favor of recognizing the contrastive direction as a special and independent direction of linguistics.

It can be stated that the largest factual material has been accumulated to date in the framework of comparative linguistics, but contrast studies have become insufficiently widespread, they are just beginning to develop.

Let's consider some important aspects of the application of contrastive research in linguistics, especially since recently there has been a significant increase in interest in them. This interest seems to be related to (1) the need to systematize the universal features of language material; (2) the desire to describe the national picture of the world of speakers of different languages; (3) the need to improve bilingual dictionaries, which indicate the nationalspecific features of the semantics of translation correspondences; (4) interest in studying the national specifics of language thinking and the national specifics of semantics and pragmatics; (5) increasing interest in the language consciousness of native speakers and the desire to describe group, social, gender, age and other features of the language, etc. ${ }^{36} ;(6)$ expanding the scope of foreign language teaching.

Modern research on contrastive linguistics is characterized not only by a variety of opinions about the goals and direction, but also by a variety of methods. A large number of scientific works are aimed at the study of transformational grammar, ideas about deep and surface structures. In the field of comparative research in grammar there is an ever deeper

36 Стернин И.А., Стернина М.А. Актуальные проблемы сопоставительных исследований в современной лингвистике. Социальные и гуманитарные знания. 2015. № 1. C. 59-65. 
differentiation of different areas, one of which is the contrastive study of the grammar of evaluation ${ }^{37}$.

\section{2. "Contrastive studies of grammar of evaluation": the problem of description}

Modern linguistics is developing rapidly, scientific and linguistic paradigms are changing, interdisciplinary explorations are being formed at the intersection of linguistics with other sciences and scientific directions. There are new directions within the actual linguistic research, which leads to the emergence of new terms and concepts, the development of a new own conceptual and terminological apparatus.

Grammar of evaluation is one of such new directions of linguistic researches, which has separated from the theory of linguoaxiology and is partially described on the Ukrainian-language material (projection on morphology).

In the East Slavic research tradition, linguoaxiology is associated primarily with the works of Nina Arutyunova, who was the first to carry out a fundamental conceptual analysis of words with the semantics of evaluation, taking into account the Western European linguistic and philosophical paradigm in historical perspective $(1988)^{38}$. Nadezhda Aksenova $(2007)^{39}$, Elena Wolf $(2002)^{40}$, Tatiana Markelova (2013) ${ }^{41}$, Elvira Stolyarova $(1988)^{42}$, Viktor Shakhovsky $(2008)^{43}$ and others became Nina Arutyunova's followers in Russian linguistics.

A complete and comprehensive study of lingua-axiological issues in Ukrainian linguistics was first carried out by Tatiana Kosmeda, which is thoroughly represented in the monographic study «Аксіологічні аспекти прагмалінгвістики: формування i розвиток категорії оцінки»

${ }^{37}$ Ковтун О.В. Проблематика лінгвоаксіології в західній дослідницькій традиції: аспектуальний огляд. Challenges and achievements of European countries in the area of philological researches : Collective monograph. Vol. 1. Riga, Latvia : "Baltija Publishing", 2020. P. 274-297.

38 Арутюнова Н.Д. Типы языковых значений. Оценка. Событие. Факт. Москва : Наука, 1988. $341 \mathrm{c.}$

39 Аксенова Н.В. Оценочные смыслы в метафоре (на материале англоязычной литературы XX века) : автореф. дис. ... канд. филол. наук. Санкт-Петербург, 2007. 19 с.

40 Вольф Е.М. Функциональная семантика оценки. 2-е изд., доп. Москва : Едиториал УРСР, 2002. 280 с.

${ }^{41}$ Маркелова Т.В. Прагматика и семантика средств выражения оценки в русском языке: монография. Москва : Москов. гос. ун-т печати им. Ивана Федорова, 2013. 299 c.

42 Столярова Э.А. Лексико-семантическое поле оценки в разговорной речи. Словарные категории: сб. статей. Москва : Наука, 1988. С. 186-191.

43 Шаховский В.И. Категоризация эмоций в лексико-семантической системе языка, изд. 2, испр. и доп. Москва, URSS, 2008. 208 с. 
("Axiological aspects of pragmalinguistics: the formation and development of the category of evaluation") (2000) ${ }^{44}$.

Grammar of evaluation stood out from the bosom of Ukrainian linguoaxiology, the issues of which were actualized by Tetyana Kosmeda in the above-mentioned monograph, as well as in a number of articles, directing the research of her graduate students (Yuriy Bulyk, Daria Ryazantseva, Oksana Khaliman). To date, morphology of evaluation as a component of grammar of evaluation has been comprehensively characterized on the material of the Ukrainian language by Oksana Haliman, which is represented in the monograph «Граматика оцінки: морфологічні категорії української мови» ("Grammar of evaluation: morphological categories of the Ukrainian language") ${ }^{45}$. We consider scientific researches prepared by T. Kosmeda and O. Haliman in co-authorship important for the theory of grammar of evaluation, among which we consider «"Граматика оцінки" як актуальна проблема сучасного мовознавства» (“Grammar of evaluation" as an urgent problem of modern linguistics") the most significant, which explains the concept of grammar of evaluation as a new scientific field, the purpose of which is a comprehensive study of grammatical means of expressing values taking into account their pragmatic characteristics $^{46}$. It is noted that "the development of the theory of grammar of evaluation involves a comprehensive description of grammatical means of expression of evaluation values, which will ensure the development of rules for the use of grammatical units in evaluation functions and interpretation of patterns of their interpretation"

The grammatical means of expression of evaluation include both morphological units and syntactic constructions, which traditionally determines the division of grammar of evaluation into two subdivisions: morphology of evaluation and syntax of evaluation, which are inextricably linked, because secondary meanings of morphological forms (including evaluation) are realized in syntagmatic relations ${ }^{48}$. O. Haliman represented the description of the whole system of noun and verb grammatical categories

${ }^{44}$ Космеда Т. Аксіологічні аспекти прагмалінгвістики: формування і розвиток категорії оцінки: монографія. Львів : ЛНУ ім. І. Франка, 2000. 349 с.

45 Халіман О.В. Граматика оцінки: морфологічні категорії української мови: монографія. Харків : Майдан, 2019. 458 с.

46 Космеда Т.А., Халіман О.В. «Граматика оцінки» як актуальна проблема сучасного мовознавства. Лінгвістичні студії. Донецьк : Донец. нац. ун-т, 2011. Вип. 22. С. 17-23.

47 Космеда Т.А., Халіман О.В. «Граматика оцінки» як актуальна проблема сучасного мовознавства. Лінгвістичні студії. Донецьк : Донец. нац. ун-т, 2011. Вип. 22. С. 17-23.

48 Халіман О.В. Граматика оцінки: морфологічні категорії української мови: монографія. Харків : Майдан, 2019. 458 с. 
through the prism of evaluation grammar, showing, in particular, the functional load of some stylistic means that create grammatical connotation and play a key role in modeling the relevant speech genres ${ }^{49}$.

In linguistic dictionaries, the term "grammar of evaluation" is not interpreted today, and the metalanguage of this latest linguistic direction has not found a fixation and a comprehensive interpretation ${ }^{50}$. Analyzing «Сучасний лінгвістичний словник» (“Modern Linguistic Dictionary") by Anatoliy Zagnitko, we note that grammar of evaluation with its metalanguage as the latest linguistic direction, interpreted and studied only in the last decade, has not found fixation and comprehensive interpretation in this dictionary yet. In particular, the term 'evaluation' is interpreted by the named scientist as: 1) an aspect of the semantics of linguistic expressions; reflection of structures of the peculiarities of the division of the objective world by speakers according to its value parameters - good or evil, benefit or harm, positive or negative, etc. in language; 2) the speaker's judgment, his attitude - approval or disapproval, encouragement, etc. - as part of the stylistic connotation ${ }^{51}$. However, Tatiana Kosmeda also considers evaluation as a logical and philosophical category, noting that "the known world is always evaluated, evaluation is evidence of the degree of knowledge of the world" philosophical basis of the assessment allows us to interpret its connection with the cognitive activity of man, as a result of which the judgment is made about the value of certain objects" ${ }^{, 53}$. The researchers emphasize that evaluation is a major category of pragmalinguistics.

In the «Сучасний лінгвістичний словник» ("Modern Linguistic Dictionary") by A. Zagnitko there are also terms аксіологічний (axiological), аксіологічність (axiological property), to which synonyms оиінність (value) and аксіологія (axiology) ${ }^{54}$ are proposed, the last ones have long been included in the terminological field of linguistics, interpreted and function within it and at the intersection with other sciences.

49 Халіман О.В. Граматика оцінки: морфологічні категорії української мови: монографія. Харків : Майдан, 2019. 458 с.

50 Ковтун О. (2020) Відображення процесу становлення метамови граматики оцінки в сучасних словниках лінгвістичних термінів (на матеріалі нового словника лінгвістичних термінів А. Загнітка). Філологічні науки на перехресті культур і циивілізацій: актуальні питання. Київ : Таврійський національний університет імені В.I. Вернадського, 2020. С. 141-144.

51 Загнітко А. Сучасний лінгвістичний словник. Вінниця : ТВОРИ, 2020. Х, 920 с.

${ }^{52}$ Космеда Т. Аксіологічні аспекти прагмалінгвістики: формування і розвиток категорії оцінки : монографія. Львів : ЛНУ ім. І. Франка, 2000. 349 с.

53 Халіман О.В. Граматика оцінки: морфологічні категорії української мови: монографія. Харків : Майдан, 2019. 458 с.

54 Загнітко А. Сучасний лінгвістичний словник. Вінниця : ТВОРИ, 2020. 920 с. 
However, meta-units interpreted and declared in grammar of evaluation, namely: граматика оцінки (grammar of evaluation), категорія оцінки (evaluative category), оцінне значення (evaluative value), оцінний смисл (evaluative meaning), аксіологічний смисл (axiological meaning), граматикалізаиія оиінних значень (grammaticalization of evaluative values), etc., are still to be included in the linguistic terminology system in general and terminological dictionaries in particular. Some of these terms have already become actively used in linguistic researches ${ }^{55}$.

In Western linguistic tradition, there are fragmentary works on linguoaxiology and evaluation grammar (Michael Halliday ${ }^{56}$, James Martin $^{57}$, Peter White ${ }^{58}$, the collective research by James Martin and Peter White $^{59}$, Susan Hunston ${ }^{60}$, Laura Hidalgo Downing ${ }^{61}$ ), however, fundamental monographic studies that would be devoted to the issue of linguoaxiology, are absent in contrast to East Slavic linguistics ${ }^{62}$.

Depending on the methodology of the scientific schools of the Western tradition, axiological linguistics has developed a certain established metalanguage, but researchers also suggest authorial terms that have not yet become traditional and are not accepted by East Slavic linguistics, in

55 Ковтун О. (2020) Відображення процесу становлення метамови граматики оцінки в сучасних словниках лінгвістичних термінів (на матеріалі нового словника лінгвістичних термінів А. Загнітка). Філологічні науки на перехресті культур $i$ цивілізацій: актуальні питання. Київ : Таврійський національний університет імені B.I. Вернадського, 2020. C. 141-144.

${ }^{56}$ Halliday M., Matthiessen Ch. M.I.M. Introduction to Functional Grammar. Third edition. London : Edward Arnold, 2004. 689 p.

${ }^{57}$ Martin J. Blessed are the Peacemakers: Reconciliation and Evaluation. Research and Practice in Professional Discourse / Christopher N Candlin (Eds.). Tat Chee Avenue, Kowloon, Hong Kong : City University of Hong Kong Press, 2002. P. 187-227.

${ }^{58}$ White P.R.R. Evaluative contents in verbal communication. Verbal communication. 2016. Vol. 3. P. 77-96.

${ }^{59}$ Martin J., White P. The Language of Evaluation. Appraisal in English. New York : Palgrave Macmillan, 2005. 278 p.

${ }^{60}$ Hunston S. Evaluation and the planes of discourse: Status and value in persuasive texts. Evaluation in Text / ed. Susan Hunston and Geoff Thomson. Oxford and New York : Oxford University Press, 2000. P. 176-206.

${ }^{61}$ Hidalgo Downing L. Grammar and Evaluation. The Encyclopedia of Applied Linguistics / Edited by Carol A. Chapelle. December 2015. URL: https://doi.org/10.1002/9781405198431.wbeal1471.

${ }^{62}$ Ковтун О.В. Проблематика лінгвоаксіології в західній дослідницькій традиції: аспектуальний огляд. Challenges and achievements of European countries in the area of philological researches : Collective monograph. Vol. 1. Riga, Latvia : "Baltija Publishing", 2020. P. 274-297. 
particular: Appraisal Framework (Michael Halliday ${ }^{63}$; James Martin and Peter White ${ }^{64}$ ), Classematics (Eugenio Coseriu ${ }^{65}$ ), evaluative appreciation (Horst Geckeler ${ }^{66}$ ), the autonomous plane and the interactive plane (John Sinclaii $^{67}$ ), the interactive evaluation (Susan Hunston ${ }^{68}$ ), topic-oriented evaluation, and research-oriented evaluation (Puleng Thetela ${ }^{69}$ ), Field of Research and Field of Domain (Susan Hood ${ }^{70}$ ), language of evaluation (Monika Bednarek $^{71}$ ), a local grammar of evaluation (Susan Hunston ${ }^{72}$ ). We can state that most of these terms are not yet recorded in dictionaries of linguistic terms and need to be clarified and developed ${ }^{73}$.

The volume of scientific works devoted to the analysis of the process of verbalization including the grammaticalization of evaluation by morphological and syntactic means in recent years testifies to the interest in this problem, which remained out of Western linguistic tradition and deserves active study today. The problem of supplementing the already existing theory devoted to grammatical mechanisms of generation of evaluation and research of all grammatical potential of language through a prism of grammar of evaluation on the basis of English remains urgent ${ }^{74}$.

${ }^{63}$ Halliday M., Matthiessen Ch. M.I.M. Introduction to Functional Grammar. Third edition. London : Edward Arnold, 2004. 689 p.

${ }^{64}$ Martin J., White P. The Language of Evaluation. Appraisal in English. New York : Palgrave Macmillan, 2005. 278 p.

${ }^{65}$ Coseriu E. Principios de Semántica Estructural. Madrid : Gredos, 1977. 246 p.

${ }^{66}$ Geckeler H. Strukturelle Semantik und Wortfeldtheorie. Munich : Fink, 1971. 255 p.

${ }^{67}$ Sinclair J. Planes of discourse. The two-fold voice: essays in honour of Ramesh Mohan / ed. S.N.A. Rizvi. Salzburg : University of Salzburg, 1981. P. 70-89.

${ }^{68}$ Hunston S. Evaluation and the planes of discourse: Status and value in persuasive texts. Evaluation in Text / ed. Susan Hunston and Geoff Thomson. Oxford and New York : Oxford University Press, 2000. P. 176-206.

${ }^{69}$ Thetela P. Evaluated entities and parameters of value in academic research articles. English for Specific Purposes 16, 1997. P. 101-118.

${ }^{70}$ Hood S. Appraising Research: Taking a stance in academic writing. Sydney: University of Technology PhD thesis, 2004. 227 p.

${ }^{71}$ Bednarek M. Evaluation in Text Types. Special Issue of Functions of Language 15.1. Amsterdam: John Benjamins, 2008. 192 p.

${ }^{72}$ Hunston S. Patterns, constructions and local grammar: a case study of 'evaluation'. Applied Linguistics. 40, 4, 2019. P. 567-593.

${ }^{73}$ Ковтун О.В. Проблематика лінгвоаксіології в західній дослідницькій традиції: аспектуальний огляд. Challenges and achievements of European countries in the area of philological researches : Collective monograph. Vol. 1. Riga, Latvia : "Baltija Publishing", 2020. P. 274-297.

${ }^{74}$ Ковтун О.В. Проблематика лінгвоаксіології в західній дослідницькій традиції: аспектуальний огляд. Challenges and achievements of European countries in the area of philological researches : Collective monograph. Vol. 1. Riga, Latvia : "Baltija Publishing", 2020. P. 274-297. 
There is a need to develop a new direction - contrastive grammar of evaluation, because the comparison of grammatical means of explication of evaluation will serve to deepen the study of the problem, to understand the inner essence of language, to fully describe the terminological field of metalanguage of evaluation. Of course, contrastive grammar of evaluation should also be developed taking into account the division of grammar into morphology and syntax, i.e. contrastive morphology of evaluation and contrastive syntax of evaluation ${ }^{75}$.

\section{CONCLUSIONS}

The terminological field of contrastive grammar still remains insufficiently developed, the terms need to be clarified and supplemented. We can state that although this linguistic direction has a long research tradition, its metalanguage continues to develop and improve. We trace the unjustified synonymy of some terms (comparative grammar, confrontational grammar, contrastive grammar), which leads to controversy among linguists and attempts to make appropriate clarifications to neutralize synonymy.

Having considered the system of terms that function in the professional discourse of textbooks on contrastive grammar, scientific research on it, as well as comparative linguistics, terminological dictionaries, we consider it appropriate to consider the terms contrastive grammar, comparative grammar and confrontational grammar as synonymous.

However, the term contrastive grammar seems to most accurately reflect the essence of the educational goal - the comparison of descriptive grammars of several languages, the opposition and comparison of allomorphic features. In addition, this term "sounds" the same in all three languages, on the material of which the actual contrast analysis will be carried out.

It should also be noted that despite the large amount of scientific literature devoted to the study of the category of comparison, its linguistic "territory" has not yet been delineated, the nature of this phenomenon, its linguistic status and specifics of interaction with other related categories (categories of ratio, correlation, graduality, quantity, intensity, uncertainty, evaluation, etc.) have not been clarified, its functionality in language is not described, its semantic structure and the most complete inventory of explicators of this structure are not defined.

Cognitive-creative process of establishing similarities and differences between objects of the environment is associated with other tasks of linguo-

${ }^{75}$ Ковтун О.В. Інтерпретація напряму «зіставне дослідження граматики оцінки». Збірник тез доповідей Всеукраӥнської наукової конференцї «Актуальні питання вивчення германських, романських $і$ слов'янських мов $i$ літератур та методики викладання іноземних мов». Вінниця : ДонНУ імені Василя Стуса, 2021. С. 45-48. 
creative and thought-making human activity - communicative, pragmatic, aesthetic, because comparison is not only the process of defining something, but also finding the definition of the indefinite, i.e. the designation of the phenomenon with not fully clarified parameters. Pragmatics of cognitive and speech activity of the speaker seeks to solve specific tasks - to isolate, identify the object so that it acquires at least a certain delineation, which will allow to know it in the future, including in the focus of the category of evaluation.

The direction of contrastive grammar of evaluation is undoubtedly promising, as the study of grammar of evaluation can be carried out on the basis of Slavic and non-Slavic languages, which is extremely important for the development of theoretical foreign language courses (including English), theory and practice of translation studies, foreign language teaching methods. Its development will help solve important linguistic problems and problems of methods of teaching linguistic disciplines.

In our further research we consider it expedient to conduct contrastive studies of grammar of evaluation on the basis of Ukrainian, Russian and English, as it will allow comparing Ukrainian with a related language, as well as with the language of another family, which will deepen knowledge about the native language, its cultural, lexical, semantic and grammatical features, will allow to clarify and supplement the metalanguage of evaluation grammar not only on the material of the Ukrainian language, but also English, which is an urgent need.

\section{SUMMARY}

The study offers an overview of different interpretations of key terms in the professional discourse of textbooks of contrastive grammar. The terminological field of contrastive grammar still remains insufficiently developed, the terms need to be clarified and supplemented. We trace the unjustified synonymy of terms (comparative grammar, confrontational grammar, contrastive grammar), which leads to controversy among linguists and attempts to make appropriate clarifications to neutralize the synonymy. We can state that this linguistic direction is quite new, its metalanguage is still in the process of development and formation. In line with contrastive grammar, new linguistic directions are emerging, and contrastive grammar of evaluation is one of them. This direction is promising, as the study of grammar of evaluation can be carried out on the basis of Slavic and non-Slavic languages, which is extremely important for the development of theoretical foreign language courses (including English), theory and practice of translation studies, foreign language teaching methods. Its development will help solve important linguistic problems and problems of methods of teaching linguistic disciplines. In our further research we consider it expedient to conduct contrastive studies of grammar of evaluation on the basis of Ukrainian, Russian and English, as it will allow comparing Ukrainian with a 
related language, as well as with the language of another family, which will deepen knowledge about the native language, its cultural, lexical, semantic and grammatical features, will allow to clarify and supplement the metalanguage of evaluation grammar not only on the material of the Ukrainian language, but also English, which is an urgent need.

\section{REFERENCES}

1. Аксенова Н.В. Оценочные смыслы в метафоре (на материале англоязычной литературы XX века) : автореф. дис. ... канд. филол. наук. Санкт-Петербург, 2007. 19 с.

2. Аракин В.Д. Сравнительная типология английского и русского языков : Учебное пособие. 3-е издание. Москва : Физматлит, 2005. 232 с.

3. Арутюнова Н.Д. Типы языковых значений. Оценка. Событие. Факт. Москва : Наука, 1988. 341 с.

4. Вольф Е.М. Функциональная семантика оценки. 2-е изд., доп. Москва : Едиториал УРСР, 2002. 280 с.

5. Востоков А.X. Грамматика церковнославянского языка, изложенная по древнейшим оного письменным памятникам. СанктПетербург : в тип. Имп. акад. наук, 1863. 134 с.

6. Гак В.Г. О контрастивной лингвистике. Новое в зарубежной лингвистике. Москва : Прогресс, 1989. 438 с.

7. Гладуш Н.Ф., Павлюк Н.В. Contrastive Grammar: Theory and Practice. Київ: Київський ун-т. ім. Б. Грінченка ; Нац. ун-т КиєвоМогилянська акад., 2019. 296 с.

8. Гудавичюс А. Сопоставительная семасиология литовского и русского языков. Вильнюс : Мокслас, $1985.176 \mathrm{c}$.

9. Свтушенко H.I. Контрастивний та зіставний аспекти досліджень у сучасній лінгвістичній. Наукові праці Чорноморського державного університету імені Петра Могили комплексу «Києво-Могилянська академія». Серія : Філологія. Мовознавство. 2014. Т. 221. Вип. 209. C. 24-28.

10.Загнітко Анатолій. Словник сучасної лінгвістики: поняття і терміни. Донецьк : ДонНУ, 2012. Т. 2. 350 с.

11. Загнітко А. Сучасний лінгвістичний словник. Вінниця : ТВОРИ, $2020.920 \mathrm{c}$.

12. Исенова Ф.К. Сопоставительное языкознание и контрастивная лингвистика в современной языковой парадигме. Вестник КарГУ. Сер. филологическая. Караганда : КарГУ, 2007. № 1. С. 71-77.

13. Касевич В.Б. Фонология в типологическом и сопоставительном изучении языков: Методы сопоставительного изучения языков. Москва : Наука, 1981. 94 с.

14. Ковтун О. Відображення процесу становлення метамови граматики оцінки в сучасних словниках лінгвістичних термінів 
(на матеріалі нового словника лінгвістичних термінів А. Загнітка). Філологічні науки на перехресті культур $і$ иивілізацій: актуальні питання. Київ : Таврійський національний університет імені B.I. Вернадського, 2020. С. 141-144.

15. Ковтун О.В. Інтерпретація напряму «зіставне дослідження граматики оцінки». Збірник тез доповідей Всеукраїнської наукової конференції «Актуальні питання вивчення германських, романських $i$ слов'янських мов і літератур та методики викладання іноземних мов». Вінниця : ДонНУ імені Василя Стуса, 2021. С. 45-48.

16. Ковтун О.В. Проблематика лінгвоаксіології в західній дослідницькій традиції: аспектуальний огляд. Challenges and achievements of European countries in the area of philological researches: Collective monograph. Vol. 1. Riga, Latvia : "Baltija Publishing", 2020. P. 274-297.

17. Космеда Т. Аксіологічні аспекти прагмалінгвістики: формування і розвиток категорії оцінки : монографія. Львів : ЛНУ ім. І. Франка, 2000. 349 c.

18. Космеда Т.А., Халіман О.В. «Граматика оцінки» як актуальна проблема сучасного мовознавства. Лінгвістичні студіï. Донецьк : Донец. нац. ун-т, 2011. Вип. 22. С. 17-23.

19. Кочерган М.П. Основи зіставного мовознавства : підручник. Київ : Академія, 2006. 424 с.

20. Лингвистический энциклопедический словарь / гл. ред. В.Н. Ярцева. Москва : Советская энциклопеция, 1990. 688 с.

21. Маркелова Т.В. Прагматика и семантика средств выражения оценки в русском языке: монография. Москва : Москов. гос. ун-т печати им. Ивана Федорова, 2013. 299 с.

22. Мокиенко В.M. Сопоставление в теории и практике преподавания русского языка как иностранного. Русский язык за рубежом. 1987. № 5. С. 54-60.

23. Селігей П.О. Мовна свідомість: структура, типологія, виховання / НАН України. Інститут мовознавства ім. О.О. Потебні. Київ : Вид. дім «Києво-Могилянська академія». 2012. С. 13 (118 с.)

24. Стернин И.А., Стернина М.А. Актуальные проблемы сопоставительных исследований в современной лингвистике. Социальные $u$ гуманитарные знания. 2015. № 1. С. 59-65.

25. Сулейменова Э.Д. Казахский и русский языки: основы контрастивной лингвистики. Алматы : Демеу, 1996. 208 с.

26. Халіман О.В. Граматика оцінки: морфологічні категорії української мови: монографія. Харків : Майдан, 2019. 458 с.

27. Хельбиг Г. Языкознание - сопоставление - преподавание иностранных языков. Новое в зарубежной лингвистике. Москва : Прогресс, 1989. Вып. XXV. Контрастивная лингвистика. С. 307-326. 
28. Шаховский В.И. Категоризация эмоций в лексикосемантической системе языка, изд. 2, испр. и доп. Москва, URSS, 2008. 208 c.

29. Ярцева В.Н. Контрастивная грамматика. Москва : Наука, $1981.111 \mathrm{c}$.

30. Bally Ch. Traité de Stylistique Française. (3rd. ed., 2 vol.) Paris : C. Klincksiek, 1951. 264 p.

31. Bednarek M. Evaluation in Text Types. Special Issue of Functions of Language 15.1. Amsterdam : John Benjamins, 2008. 192 p.

32. Bopp F. A Comparative Grammar of the Sanscrit, Zend, Greek, Latin, Lithuanian, Gothic, German and Sclavonic Languages. London : Williams, $1885.456 \mathrm{p}$.

33. Coseriu E. Principios de Semántica Estructural. Madrid : Gredos, 1977. $246 \mathrm{p}$.

34. Geckeler H. Strukturelle Semantik und Wortfeldtheorie. Munich : Fink, 1971. 255 p.

35. Grimm J. Geschichte Der Deutschen Sprache. Erster Band. Leipzig, 1853. 1250 gr.

36. Halliday M., Matthiessen Ch. M.I.M. Introduction to Functional Grammar. Third edition. London : Edward Arnold, 2004. 689 p.

37. Hidalgo Downing L. Grammar and Evaluation. The Encyclopedia of Applied Linguistics / Edited by Carol A. Chapelle. December 2015. URL: https://doi.org/10.1002/9781405198431.wbeal1471.

38. Hood S. Appraising Research: Taking a stance in academic writing. Sydney : University of Technology PhD thesis, 2004. 227 p.

39. Hunston S. Evaluation and the planes of discourse: Status and value in persuasive texts. Evaluation in Text / ed. Susan Hunston and Geoff Thomson. Oxford and New York : Oxford University Press, 2000. P. 176-206.

40. Hunston S. Patterns, constructions and local grammar: a case study of 'evaluation'. Applied Linguistics. 40, 4, 2019. P. 567-593.

41. Karamysheva I.D. Contrastive grammar of English and Ukrainian Languages: Textbook; Second edition, revised. Vinnytsia : Nova Knyha Publishers, 2012. 320 p.

42. Khan G. Encyclopedia of Hebrew Language and Linguistics. Brill, 2013.

43. Lado R. Linguistics Across Cultures: Applied Linguistics for Language Teachers. University of Michigan Press, 1957. 141 p.

44. Martin J. Blessed are the Peacemakers: Reconciliation and Evaluation. Research and Practice in Professional Discourse / Christopher N Candlin (Eds.). Tat Chee Avenue, Kowloon, Hong Kong : City University of Hong Kong Press, 2002. P. 187-227. 
45. Martin J., White P. The Language of Evaluation. Appraisal in English. New York : Palgrave Macmillan, 2005. 278 p.

46. Meehan P., Gomez Calvillo N., Díaz M. J., Rolfi L. Contrastive grammar: a theory and practice handbook. Córdoba : Asociación Cooperadora Facultad de Lenguas - UNC, 2017. 245 p.

47. Rask R. Ch. A Grammar of the Danish language for the use of Englishmen, 1830.

48. Sinclair J. Planes of discourse. The two-fold voice: essays in honour of Ramesh Mohan / ed. S.N.A. Rizvi. Salzburg : University of Salzburg, 1981. P. 70-89.

49. Thetela P. Evaluated entities and parameters of value in academic research articles. English for Specific Purposes 16, 1997. P. 101-118.

50. White P.R.R. Evaluative contents in verbal communication. Verbal communication. 2016. Vol 3. P. 77-96.

\section{Information about the author: Kovtun O. V., orcid.org/0000-0002-9139-8987 $\mathrm{PhD}$ in Philology,} Associate Professor at the Department of the Theory and Practice of

Translation of the Faculty of Foreign Languages Vasyl' Stus Donetsk National University 21, 600-richchia str., Vinnytsia, 21021, Ukraine 